\title{
Fauna associated with Malayan filariasis transmission in Banyuasin, South Sumatra, Indonesia
}

\author{
Budi Mulyaningsih ${ }^{1}$ (D), Sitti Rahmah Umniyati1 ${ }^{(D)}$, Suwarno Hadisusanto² ${ }^{(D)}$ and Erwin Edyansyah ${ }^{3}$ (D) \\ 1. Department of Parasitology, Faculty of Medicine Public Health and Nursing, Universitas Gadjah Mada, Yogyakarta, \\ Indonesia; 2. Department of Tropical Biology, Faculty of Biology, Universitas Gadjah Mada, Yogyakarta, Indonesia; \\ 3. Postgraduate Program of Medicine, Faculty of Medicine Public Health and Nursing, Universitas Gadjah Mada, \\ Yogyakarta, Indonesia. \\ Corresponding author: Budi Mulyaningsih, e-mail: budi.mulyaningsih@ugm.ac.id \\ Co-authors: SRU: sitti-rahmah@ugm.ac.id, SH: suwarnohs@ugm.ac.id, EE: erwin.edyansyah@mail.ugm.ac.id \\ Received: 24-12-2020, Accepted: 17-06-2021, Published online: 28-07-2021
}

doi: www.doi.org/10.14202/vetworld.2021.1954-1959 How to cite this article: Mulyaningsih B, Umniyati SR, Hadisusanto S, Edyansyah E (2021) Fauna associated with Malayan filariasis transmission in Banyuasin, South Sumatra, Indonesia, Veterinary World, 14(7): 1954-1959.

\begin{abstract}
Background and Aim: Brugia malayi is known to be zoonotically important because it can be transmitted from animals (mammals and primates) to humans or from humans to humans through mosquito vectors. This study was conducted to explore the fauna associated with Malayan filariasis transmission in Sedang village, Suak Tapeh District, Banyuasin Regency, South Sumatra Province, Indonesia.

Materials and Methods: A cross-sectional research design with an observational and analytical approach was applied in this study, and it was conducted in May 2018. Mosquitoes were collected twice using human bait both inside and outside the house from 6:00 p.m. to 6:00 a.m. The presence of competitors, predators, and reservoir hosts in the areas of five breeding habitats of Mansonia spp. was observed. The presence of microfilaria was confirmed under a microscope in night blood samples of inhabitants and cats. The presence of infective larvae (L3) of B. malayi was identified microscopically and based on the polymerase chain reaction method in female Mansonia mosquitoes.
\end{abstract}

Results: A total of 12 mosquito species were found, among which Mansonia uniformis was the dominant mosquito, and the predominant competitor was Mansonia annulifera. Dragonflies, as predators were found in two breeding habitats and fish were found in one breeding habitat. The L3 of B. malayi were not identified in the mosquitoes, and the microfilariae of $B$. malayi were not found in the blood samples of inhabitants and cats.

Conclusion: Although Mansonia mosquito population was abundant in Banyuasin Regency, the mosquito was not confirmed as an intermediate host of $B$. malayi, and the cat was not confirmed as a reservoir of $B$. malayi in the location.

Keywords: Brugia malayi, lymphatic filariasis, Mansonia uniformis, South Sumatera, subperiodic nocturnal.

\section{Introduction}

Lymphatic filariasis is an infectious and chronic disease caused by Wuchereria bancrofti, Brugia malayi, and Brugia timori and is a major health problem in several tropical and subtropical countries. In 2004, an estimated 120 million people suffered from filariasis in 73 filariasis-endemic countries with an estimated 1.3 billion people in the filariasis transmission area $[1,2]$. This disease is widespread in almost all provinces in Indonesia. Nationally, during a period of 10-12 years, there was a significant increase in the number of cases and sufferers, from around 6500 cases in 2002 to 12,066 cases in 2011 and then to 14,932 cases in 2014, spreading in 418 districts/cities in 34 provinces. Epidemiologically, these data indicate that Indonesia is a high-risk area of contracting

Copyright: Mulyaningsih, et al. Open Access. This article is distributed under the terms of the Creative Commons Attribution 4.0 International License (http://creativecommons.org/licenses/ by/4.0/), which permits unrestricted use, distribution, and reproduction in any medium, provided you give appropriate credit to the original author(s) and the source, provide a link to the Creative Commons license, and indicate if changes were made. The Creative Commons Public Domain Dedication waiver (http:// creativecommons.org/publicdomain/zero/1.0/) applies to the data made available in this article, unless otherwise stated. filariasis [3,4]. Lymphatic filariasis caused by $B$. malayi in South Sumatra Province is found in almost all districts, and until 2015, there were 232 patients with chronic filariasis. Banyuasin is one of the districts with numerous cases of filariasis, with several villages being included as high-endemic areas with Malayan filariasis [5]. In some endemic areas, the transmission of parasites is still occurring, which is indicated by the discovery of new clinical filariasis cases every year. The endemicity of an area reflects the interaction of several factors, that is, hosts (genetic and immunological), parasites (types, strains, and infective doses), mosquito vectors, and their environment [6,7]. Sedang village is an area with several rivers, paddy fields, and swamp forests, which are suitable Mansonia breeding habitats that can act as zoonotic Malayan filariasis vectors. B. malayi is known to be zoonotic because it can be transmitted from animals (mammals and primates) to humans or from humans to humans through mosquito vectors $[8,9]$. The existence of mosquitoes as a vector of filariasis transmission plays a key role in its spread that is associated with the environmental conditions and behavior of the locals. Some Mansonia spp. can be vectors of the zoonotic nocturnal subperiodic 
type of $B$. malayi $[10,11]$. According to some studies conducted in South Sumatra, the primary vectors of the zoonotic nocturnal subperiodic types of $B$. malayi are Mansonia uniformis and Anopheles nigerrimus; however, in Africa, M. uniformis and Mansonia africana are the vectors of $W$. bancrofti $[12,13]$. In Tanah Bumbu, South Kalimantan Province, Safitri [14] in 2012 found a mosquito species that was microscopically confirmed as a filariasis vector based on the presence of the infective larvae (L3) of B. malayi in M. uniformis, with an infective rate of $14.29 \%$. It is also necessary to control the animal reservoirs that can be sources of filariasis infection. Studies conducted on cats (Felis catus) in Jambi reported that 33.3\% (5 of 15$)$ were infected with $B$. malayi $[15,16]$. Several species of mosquitoes belonging to four principal genera, namely, Anopheles, Culex, Aedes, and Mansonia, transmit filariasis. Their distribution, ecology, biology, and transmission potential vary significantly. Certain mosquito species occupy specific habitats, such as those with certain water quality requirements, namely, dissolved oxygen levels. For instance, the quality of life of Culex quinquefasciatus larvae will rapidly decrease at $\mathrm{pH} 9.4$ [17].

It is important to understand the entomological aspects of the transmission of lymphatic filariasis because the transmission efficiency differs considerably according to the vector species [18]. The zoonotic nocturnal subperiodic type of $B$. malayi is transmitted by Mansonia spp. and can spread from animals to humans. One of the problems in the attempts to eliminate filariasis in Indonesia is the presence of animals that become reservoir hosts $[12,19]$. It is necessary to examine certain factors that play an important role in the spread of lymphatic filariasis to break the transmission chain. The best approach to break the transmission chain is case management (treatment of filariasis) and continuously observes filariasis vectors as the basis for vector eradication and eliminating mosquito breeding places $[11,20]$.

The environment is highly influential on the transmission chain and the distribution of filariasis cases. The present study was conducted to evaluate the fauna associated with the transmission of Malayan filariasis, that is, the presence of M. uniformis as a vector, the presence of various species of mosquitoes as competitors, the predators that feed on mosquito larvae, and the presence of animals as reservoir hosts.

\section{Materials and Methods}

\section{Ethical approval}

This study has been approved by the Ethics Commission for Medical and Health Research, Faculty of Medicine, Public Health and Nursing, Universitas Gadjah Mada, Yogyakarta-Indonesia, with reference number: KE/FK/0389/EC/2018.

\section{Study design, period, and location}

The study was conducted in May 2018. The research design was a cross-sectional survey and was conducted in Sedang Village, Suak Tapeh Subdistrict, Banyuasin District, South Sumatera Province, Indonesia.

\section{Mosquito collection and identification}

Adult mosquitoes were captured using the human-landing method, which was performed by six people, with three people in the house and three people outside the house, for $12 \mathrm{~h}$ from 6:00 p.m. to 6:00 a.m., and it was performed in two consecutive nights. The captured mosquitoes were collected and then identified under a dissecting microscope $[5,10]$. The presence of L3 of B. malayi was identified microscopically and based on the polymerase chain reaction (PCR) method in female Mansonia mosquitoes.

\section{Observation of physical and biological factors}

Ecosystem observations, including physical and biological factors, were performed in five places that were suspected of being Mansonia spp. breeding habitats. Physical factors included temperature (water, air, and soil), humidity, soil moisture, $\mathrm{pH}$ (water and soil), light intensity, clouds, and wind velocity. Biological factors included competitors and predators of M. uniformis, reservoir hosts of the nocturnal subperiodic type of $B$. malayi, and the abundance of plants found around the breeding place of Mansonia spp. The map coordinates and environmental conditions of each breeding habitat were observed and recorded.

\section{Blood sample collection and identification of microfilaria}

The presence of microfilaria was confirmed under a microscope in night blood samples of inhabitants and cats. In this study, six cats were examined for blood microscopically and based on the PCR method to determine the presence of $B$. malayi L3. The PCR assay was performed using the forward primer HhaI (5'GCGCATAAATTCATCAGC-3') and the reverse primer HhaII (5'GCGCAAAACTTAATTACAAAAGC- $3^{\prime}$ ). The PCR products were subjected to electrophoresis the results of which were positive if there were any bands with a size of $322 \mathrm{bp}$ that formed [21].

\section{Results}

A total of 426 mosquitoes were collected during the study, which consisted of five genera, that is, Mansonia, Culex, Malaya, Armigeres, and Aedes. $M$. uniformis constituted the maximum percentage (36.62\% [156/426]) of mosquitoes collected using the landing method (Table-1). According to the study conducted by Pratiwi [22] from December 2016 to March 2017 using the indoor and outdoor human-landing collection method, there were 8239 mosquitoes consisting of 12 genera and 38 species. The genus Mansonia was found to be the most dominant in Sedang village. Further analysis revealed that environmental characteristics and the presence of aquatic plants played a key role in the diversity, abundance, and domination of mosquitoes. The existence and survival of 
mosquitoes are strongly influenced by the conditions of their breeding habitats. All vectors live according to local ecological conditions, including those living in brackish water at a certain level of salinity, whereas there are some vectors living in rice fields, along with clean water in the mountains and pools of water that can be exposed to sunlight [23]. Topographically, Sedang village is an area with several rivers, paddy fields, and swamp forests that are suitable for the breeding of Mansonia spp. Sedan village is also an area consisting of most of the agriculture, rubber, and oil palm plantations. In the present study, ecosystem observations, including physical and biological factors, were performed in five places that comprised the common types of breeding areas of Mansonia spp.

Among the five breeding habitats in Sedang village, Mansonia spp. larvae were commonly found in breeding sites 2, 4, and 5; however, in breeding habitats 1 and 3, there were no Mansonia spp. larvae. The other insects found in breeding sites 2 and 5 were the adults and larval stages of the dragonfly, which can act as a predator as they feed on mosquito larvae. Fish were found in breeding habitat 5 , which can also be a predator for mosquito larvae. Dragonfly and fish were found in the breeding habitats with numerous mosquito larvae because of the abundance of their food (mosquito larvae). Cats were found in every breeding habitat area and can act as reservoir hosts of the nocturnal subperiodic type of B. malayi (Table-2). We

Table-1: The number and percentage of mosquitoes caught in Sedang Village, Suak Tapeh Subdistrict, Banyuasin District, South Sumatera Province, Indonesia.

\begin{tabular}{lcc}
\hline Mosquito species & $\begin{array}{c}\text { Number of } \\
\text { mosquito }\end{array}$ & $\begin{array}{c}\text { Percentage of } \\
\text { mosquito }\end{array}$ \\
\hline Mansonia uniformis & 156 & 36.62 \\
Mansonia annulifera & 93 & 21.83 \\
Mansonia dives & 4 & 0.94 \\
Culex gelidus & 21 & 4.93 \\
Culex vishnui & 6 & 1.41 \\
Culex quinquefasciatus & 76 & 17.84 \\
Culex tritaeniorhynchus & 4 & 0.94 \\
Culex fuscosephalus & 25 & 5.87 \\
Malaya spp. & 9 & 2.12 \\
Armigeres subalbatus & 22 & 5.16 \\
Aedes aegypti & 9 & 2.11 \\
Aedes albopictus & 1 & 0.23 \\
Total number of mosquitoes & 426 & 100 \\
\hline
\end{tabular}

analyzed the physical factors in the five breeding habitats of Mansonia spp., including temperature, humidity, light, wind, and $\mathrm{pH}$ of water and soil (Table-3).

In breeding habitat 2 , the temperature of water, air, and soil was almost optimal $\left(24-26^{\circ} \mathrm{C}\right)$ for insect growth and development, and in breeding habitat 2 , the maximum number of Mansonia spp. larvae was found. Mansonia spp. larvae were found on the roots of several water plants such as Ipomoea aquatica, Eich hornia crassipes, and Limnocharis flava in breeding sites 2, 4, and 5 in Sedang village. These water plants are highly essential for the growth and development of Mansonia, as they are extremely suitable for attaching the egg, larva, and pupa of Mansonia spp. The abundance of plants found in each of the breeding habitats of Mansonia spp. is shown in Table-4.

We found negative results in the microscopic examination and the molecular PCR method conducted to identify the L3 of B. malayi in female Mansonia mosquitoes. This finding indicates that filarial larvae were not detected in all the captured mosquito species.

\section{Discussion}

Epidemiologically, the transmission of lymphatic filariasis involves several complex factors, such as the presence of lymphatic filarial worms as agents of disease, humans as hosts, adult mosquitoes as vectors, and physical, biological, and social environmental factors. The environment is highly influential on the distribution and transmission chain of filariasis cases. The biological environment involved in the transmission chain of filariasis includes the presence of aquatic plants as a place of Mansonia spp. growth, the presence of other mosquitoes as competitors, the presence of other insects or animals as predators, and the presence of animals as reservoir hosts.

Although the population of Mansonia mosquitoes was found to be abundant in this study, no $B$. malayi L3 were identified. Therefore, Mansonia mosquitoes were not confirmed as an intermediate host of B. malayi in this study. The microfilariae of $B$. malayi were also not found in cat blood samples in this study; therefore, cats were not confirmed as the reservoir of $B$. malayi in this location. Similarly, a study conducted in 2006 in Sungai Rengit village, Banyuasin Regency, South Sumatra [23], and a study conducted in 2011 in Muara Padang village, Banyuasin

Table-2: Distribution of competitor, predator, and reservoir host in five Mansonia spp., breeding habitat areas in Sedang Village, Suak Tapeh Subdistrict, Banyuasin District, South Sumatra Province, Indonesia.

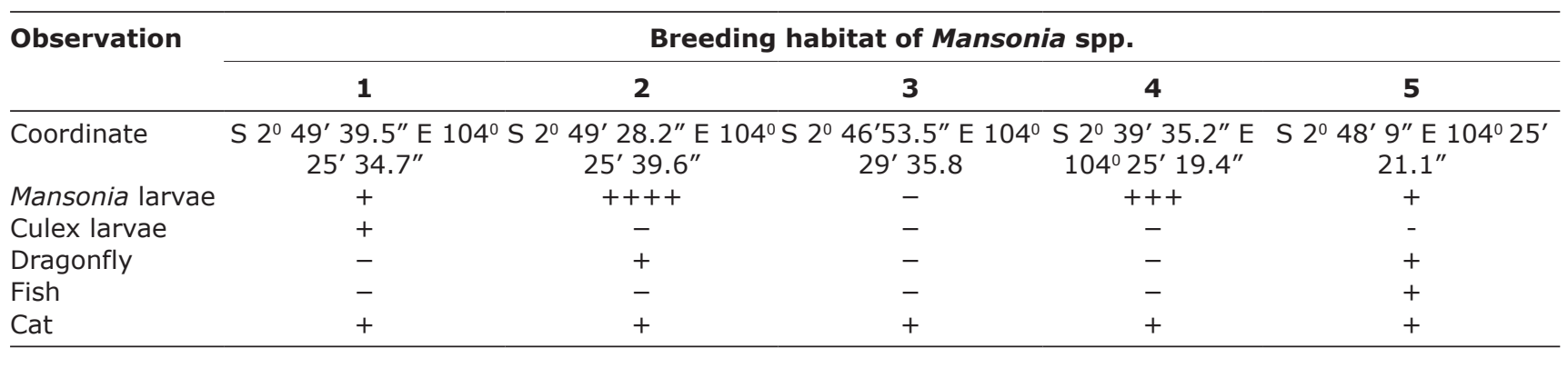


Table-3: Physical factors of five Mansonia spp. breeding habitats in Sedang Village, Suak Tapeh Subdistrict, Banyuasin District, South Sumatera Province, Indonesia.

\begin{tabular}{lccccc}
\hline Observation & \multicolumn{5}{c}{ Breeding habitat of Mansonia } \\
& $\mathbf{5}$ & $\mathbf{2}$ & $\mathbf{3}$ & $\mathbf{4}$ & $\mathbf{5}$ \\
\cline { 2 - 6 } & $\mathbf{1}$ & $\mathbf{2}$ & \\
\hline Water temperature & $28^{\circ} \mathrm{C}$ & $24^{\circ} \mathrm{C}$ & $31^{\circ} \mathrm{C}$ & $24^{\circ} \mathrm{C}$ & $28^{\circ} \mathrm{C}$ \\
Air temperature & $31^{\circ} \mathrm{C}$ & $26^{\circ} \mathrm{C}$ & $35^{\circ} \mathrm{C}$ & $32^{\circ} \mathrm{C}$ & $32^{\circ} \mathrm{C}$ \\
Soil temperature & $29^{\circ} \mathrm{C}$ & $25^{\circ} \mathrm{C}$ & $30^{\circ} \mathrm{C}$ & $29^{\circ} \mathrm{C}$ & $30^{\circ} \mathrm{C}$ \\
Humidity & $70 \%$ & $86 \%$ & $59 \%$ & $86 \%$ & $74 \%$ \\
Soil moisture & $79 \%$ & $90 \%$ & $75 \%$ & $90 \%$ & $86 \%$ \\
pH of water & 6.0 & 5.9 & 4.1 & 6 & 6.1 \\
pH of soil & 6.4 & 5.6 & 5.9 & 5.5 & 4.5 \\
Light intensity & 445 & 147 & 798 & 147 & 712 \\
Claudy & $70 \%$ & $65 \%$ & $90 \%$ & $60 \%$ & $55 \%$ \\
Wind velocity & 0.095 & 0.096 & 0.096 & 0.96 & 1.87 \\
\hline
\end{tabular}

Table-4: The abundance of plants found in each breeding habitat of the Mansonia spp. in Sedang Village, Suak Tapeh Subdistrict, Banyuasin District, South Sumatra Province, Indonesia.

\begin{tabular}{|c|c|}
\hline $\begin{array}{l}\text { Mansonia spp. } \\
\text { breeding habitat }\end{array}$ & $\begin{array}{l}\text { Abundant plants in each } \\
\text { Mansonia spp. breeding habitat }\end{array}$ \\
\hline tat 1 & $\begin{array}{l}\text { Hymenachne amplexicaulis (Rudge) } \\
\text { Nees } \\
\text { Nypa fruticans } \\
\text { Hymenachne spp. } \\
\text { Mimosa pudica } \\
\text { Ph Hymenahna yllanthus urinaria } \\
\text { (Phyllanthus niruri) } \\
\text { Azolla pinnata } \\
\text { Eichhornia crassipes }\end{array}$ \\
\hline at 2 & $\begin{array}{l}\text { Ipomoea aquatic } \\
\text { Hymenachne amplexicaulis (Rudge) } \\
\text { Nees } \\
\text { Ileusin tricocephala } \\
\text { Hymenachne spp. } \\
\text { Ageratum conyzoides } \\
\text { Hevea brasiliensis } \\
\text { Nypa fruticans }\end{array}$ \\
\hline Breeding habitat 3 & $\begin{array}{l}\text { Sonneratia caseolaris } \\
\text { Rhizophora } \\
\text { Nypa fruticans } \\
\text { Nymphaea (water lily) } \\
\text { Ileusin tricocephala } \\
\text { Azolla pinnata } \\
\text { Elaeis (oil palm) }\end{array}$ \\
\hline Breeding habitat 4 & $\begin{array}{l}\text { Azolla pinnata } \\
\text { Eichhornia crassipes } \\
\text { Limnocharis flava } \\
\text { Hymenachne spp. } \\
\text { Hymenachne amplexicaulis (Rudge) } \\
\text { Nees } \\
\text { Tracheophyta } \\
\text { Hevea brasiliensis }\end{array}$ \\
\hline Breeding habitat 5 & $\begin{array}{l}\text { Elaeis (oil palm) } \\
\text { Nymphaea (Water lily) } \\
\text { Melaleuca leucadendra syn. M. } \\
\text { leucadendron } \\
\text { Melastoma } \\
\text { Hymenachne amplexicaulis (Rudge) } \\
\text { Nees } \\
\text { Hevea brasiliensis } \\
\text { Hymenachne spp. }\end{array}$ \\
\hline
\end{tabular}

District, South Sumatra [24], reported that B. malayi L3 was not identified in the mosquitoes. Conversely, a study conducted in Narathiwat Province, South Thailand [25], and another study conducted in East Kalimantan [26] reported the presence of B. malayi microfilariae in cat blood samples.

The development of insects, including mosquitoes, is influenced by two factors, that is, the internal factors from the insects themselves and the external factors that are present in the surrounding environment where the insects live. High or low insect populations at any given time are influenced by these two factors [27]. All vectors live according to local ecological conditions. The conditions of mosquito breeding habitats are largely determined by the existing environmental conditions, such as vegetation, predators, temperature, humidity, and rainfall. A strong positive correlation exists between the abundance of mosquitoes, physical factors, and chemical factors in their breeding places [28].

Geographically, the mosquito is a cosmopolitan insect with a widespread distribution in the tropical and subtropical regions, and the changes in the environment influence the activity of the insect, which has an impact on its diversity and distribution [29]. Mosquitoes grow normally at optimum temperatures between $25^{\circ} \mathrm{C}$ and $27^{\circ} \mathrm{C}$. Low temperatures inhibit larval growth, and high temperatures kill larvae [28]. The results of this study also demonstrated the presence of Mansonia spp. in the breeding habitats with optimum temperature. Biological environment includes all the living things that are found around humans, that is, flora and fauna, which can act as a chain of filariasis transmission. Mansonia spp. are associated with swamps and large rivers on the edge of the forest or in the forest. Larvae and pupae with their siphon are attached to the roots or branches of aquatic plants such as E. crassipes, Nymphaea (water lily), and I. aquatica [11]. The vegetation in mosquito breeding habitats, including mangroves, mosses, algae, and various other plants, can affect the life of larvae as they can block sunlight or protect against other living creatures. Aquatic plants affect the breeding and survival potential of Mansonia spp. In Pistia stratiotes and E. crassipes, the aerenchyma (a soft plant tissue containing air spaces, found especially in several aquatic plants) is larger in size than that in Mimosa pudica and Azolla pinnata and can store more oxygen. The root tissues of $M$. pudica and A. piñata are more rigid and can inhibit perforation by the siphon larvae of Mansonia spp. The root structure of $P$. stratiotes and E. crassipes can reduce the effectiveness of natural predators from mosquito larvae in ponds. A. pinnata is believed to have secondary metabolites that are dangerous to Mansonia spp. larvae [30].

Endemic areas of $B$. malayi are generally found around rivers, forests, swamps, along rivers, or other water bodies overgrown with aquatic plants. Areas with different flora have different disease patterns. Swampy or muddy environment and bushes around houses are suitable breeding habitats for the Malayan 
filariasis vector (Mansonia spp.), and there exists a relationship between the presence of aquatic plants and the incidence of filariasis. Therefore, people living in endemic areas in houses with aquatic plants could have a risk of transmission of filariasis [31].

\section{Conclusion}

This study found 12 mosquito species, among which M. uniformis was the dominant mosquito, and the predominant competitor was Mansonia annulifera. The study results also indicated the presence of dragonflies as predators in two breeding sites and the presence of fish in one breeding habitat. Furthermore, despite the abundant population of Mansonia mosquitoes in Banyuasin Regency, the mosquito was not confirmed as an intermediate host of $B$. malayi, and the cat was also not confirmed as a reservoir of $B$. malayi in the location.

\section{Authors' Contributions}

BM: Designed the study. SRU and SH: Conducted the field survey. EE: Collected mosquito sample. All authors drafted, revised, read, and approved the final manuscript.

\section{Acknowledgments}

The authors express our gratitude to the various parties who have assisted in the implementation of this research, including the Head of Sedang Village, Volunteer Catchers of Mosquitoes and technicians from the Department of Parasitology, Faculty of Medicine, Public Health and Nursing Universitas Gadjah Mada, Indonesia: Mr. Purwono, Mrs. Kuswati, and Mrs. Rumbiwati for helping laboratory work. This study was financially supported by the Faculty of Medicine, Public Health and Nursing Universitas Gadjah Mada, Indonesia (Grant no.: UPPM/359/M/05/04/05.18).

\section{Competing Interests} interests.

The authors declare that they have no competing

\section{Publisher's Note}

Veterinary World remains neutral with regard to jurisdictional claims in published institutional affiliation.

\section{References}

1. World Health Organization. (2012) Global Programme to Eliminate Lymphatic Filariasis: Progress Report on Mass Drug Administration. Weekly Epidemiological Record. Vol. 87. p345-356.

2. Fenwick, A. (2018) Accelerating Progress towards Elimination of Some Neglected Topical Diseases (NTDs). International Congress on Parasitology.

3. Aditama, T.Y. (2012) Control Policy NTD'S in Indonesia. ASEAN Seminar on Neglected Tropical Diseases Committee Report, Jakarta 28-29 September.

4. Ministry of Health (MOH) Indonesia. (2015) Filariasis: Towards Filariasis Elimination 2020. Indonesian Ministry of Health Data and Information Center, Jakarta. Available from: https://bit.ly/3yXDInx. Retrieved on 15-7-2021.

5. South Sumatera Provincial Health Office. (2016) Annual Report. South Sumatra Provincial Health Office. Available from: https://bit.ly/3hDIFMi. Retrieved on 15-7-2021.

6. Cheun, H.I., Cho, S.H., Lee, H.I., Shin, E.H., Lee, J.S., Kim, T.S. and Lee, W.J. (2011) Seasonal prevalence of TT3WQ XV of Korea. Korean J. Parasitol., 49(1): 59-64.

7. Vythilingam, I. (2016) Mosquitoes of Public Health Important: Mosquitoes and Public Health. Lambert Academic Publisher, Republic of Moldova.

8. Chathuranga, W.G.D., Karunaratne, S.H.P., Fernando, B.R. and De Silva, W.A.P. (2018) Diversity, distribution, abundance, and feeding pattern of tropical ornithophilic mosquitoes. J. Vector Ecol., 43(1): 158-167.

9. Ministry of Health (MOH) Indonesia. (2005) Filariasis Epidemiology. Directorate General of Infectious Disease Control and Environmental Health, Jakarta.

10. Ministry of Health (MOH) Indonesia. (2008) Mansonia Mosquito Identification Key. Directorate General of Infectious Disease Control and Environmental Health, Jakarta.

11. Walter Reed Biosystematics Unit (WRBU). (2019) Mosquito Identification Resource. Walter Reed Army Institute of Research. Available from: Available from: http://www.wrbu.org/aors/pacom_Keys.html. Retrieved on 15-7-2021.

12. Ministry of Health (MOH) of Indonesia. (2014) Regulation of the Minister of Health of the Republic of Indonesia Number 94 of 2014 Concerning the Prevention of Filariasis, Jakarta.

13. Ughasi, J., Bekard, H.E., Coulibaly, M., Delphina, D., Gyapong, J., Appawu, M., Wilson, M.D. and Boakye, D.A. (2012) Mansonia africana and Mansonia uniformis are vectors in the transmission of Wuchereria bancrofti lymphatic filariasis in Ghana. Parasit. Vectors, 5(89): 2-5.

14. Safitri, A. (2012) Identification of Potential Vectors and Vectors in Filariasis Endemic Areas in South Kalimantan in 2012 [Final Research Report]. Tanah Bumbu Research and Development Center for Animal Source Disease Control, Tanah Bumbu.

15. 15. Sudomo, M., Oswari, E., Suwarto, and Liat, L.B. (1984) A preliminary study of Malayan filariasis in Puding Village, Jambi Province, Sumatera. Bul. Penelitian Kesehatan. 12(1): 32-38.

16. Lasbudi, P., Ambarita, and Sitorus, H. (2004) Study of mosquito population in Sebubus Village (Filariasis Endemic Areas) in South Sumatera in 2004. J. Ekol. Kesehatan, 5(1): 268-375.

17. Amarasinghe, L.D. and Dalapadado, D.R. (2014) Vector mosquito diversity and habitat variation in a semi urbanized area of Kelaniya in Srilanka. Int. J. Entomol. Res., 2(1): 15-20.

18. Mulyaningsih, B., Umniyati, S.R., Hadisusanto, S. and Edyansyah, E. (2019) Study on vector mosquito of zoonotic Brugia malayi in Musi Rawas, South Sumatera, Indonesia. Vet. World, 12(11): 1729-1734.

19. Mulyaningsih, B., Umniyati, S.R., Hadisusanto, S. and Edyansyah, E. (2019) Mansonia uniformis: A locally important vector of Brugia malayi nocturnally sub-periodic type in South Sumatera of Indonesia. Southeast Asian J. Trop. Med. Public Health, 50(4): 635-642.

20. Stojanovich, C.J. and Scott, H.G. (1966) Illustrated Key to Mosquitoes of Vietnam. Communicable Disease Center, United States.

21. Haryuningtyas, D. and Subekti, D.T. (2008) Detection of Brugia malayi microfilaria/larvae in mosquito using polymerase Chain reaction. Indones. J. Anim. Vet. Sci., 13(3): 240-248.

22. Pratiwi, R., Anwar, C., Salni, S., Hermansyah, H., Novrikasari, N., Ghiffari, A., Putra, R. and Huda, A. (2019) Species diversity and community composition of mosquitoes in a filariasis endemic area in Banyuasin District, South Sumatra, Indonesia. Biodiversitas, 20(10): 453-462. 
23. Santoso, S., Ambarita, L.P., Oktarina, R. and Sudomo, M. (2008) Epidemiology of Filariasis in Sungai Rengit Village, Talang Kelapa District, Banyuasin District, 2006. Bul. Penelitian Kesehatan, 36(2): 60-72.

24. Edyansyah, E., Soeyoko, and Sumarni, S. (2012) Epidemiology of filariasis malayi in Muara Padang Village, Muara Padang Sub District, Banyuasin District, South Sumatera, Indonesia. J. Med. Sci., 44(1): 111-116.

25. Kanjanopas, K., Choochote, W., Jitpakdi, A., Suvannadabba, S., Loymak, S., Chungpivat, S. and Nithiuthai, S. (2001) Brugia malayi in a naturally infected cat from Narathiwat Province, Southern Thailand. Southeast Asian J. Trop. Med. Public Health, 32(3): 585-587.

26. Sudjadi, F.A. (1996) Morphology Brugia malayi non-periodic causes filariasis in East Kalimantan. J. Med. Sci., 28(2): 66-71.

27. Sultana, A., Hasan, S., Hossain, M., Alim, A., Al Mamun, M. and Bashar, K. (2018) Larval breeding habitats and ecological factors influence the species composition of mosquito (Diptera: Culicidae) in the parks of Dhaka city, Bangladesh. Bangladesh J. Zool., 45(2): 111-122.

28. Arsin, A.A. (2012) Malaria in Indonesia Overview of Epidemiological Aspects. Masagena Press, Makasar.

29. Rahman, G.M.S. (2017) Manholes as an important breeding site for Culex mosquitoes in Gazipur City Corporation, Bangladesh. Bangladesh J. Zool., 45(2): 139-148.

30. Chandra, G., Ghost, A.D. and Chatterjee, S.N. (2006) Host plant preference of Mansonia mosquitoes. J. Aquat. Plant Manage., 44: 142-144.

31. Anshari, R. (2017) Risk Factor Analysis of Filariasis Incidence in Tanjung Bayur Rurar Village, Sungai Asam Village, Sungai Raya District, Pontianak Regency. Available from: http://www.eprints.undip.ac.id/thesisfilaria. Retrieved on 15-03-2017.

$* * * * * * * *$ 